\title{
Основные характеристики тувинского буддийского паломничества рубежа XIX-XX веков
}

\section{Чимиза К. Ламажаа}

Калмыцкий государственный университет им. Б. Б. Городовикова; Тувинский институт гуманитарных и прикладных социально-экономических исследований при Правительстве Республики Тыва, Российская Федерация,

\section{Ульяна П. Бичелдей}

Тувинский институт гуманитарных и прикладных социально-экономических исследований при Правительстве Республики Тыва, Российская Федерация
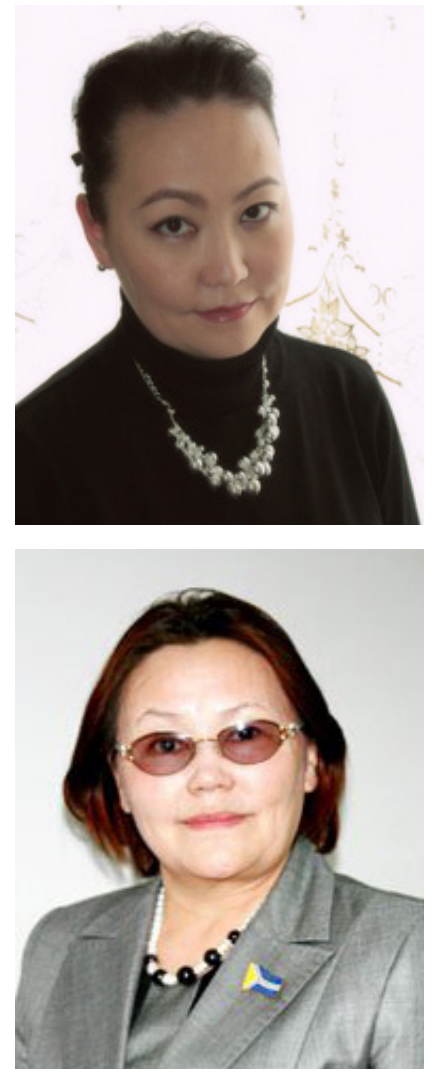

В статье впервые представлены основные характеристики буддийского паломничества тувинцев рубежа XIX-XX веков, которые сформулированы на основе изучения целого ряда источников. Хотя история появления, укрепления буддизма в Туве достаточно исследована, теме паломничества не уделялось внимания. Главной проблемой является отсутствие в исторической литературе Тувы жанра путевых заметок («хождений») самих паломников. Поэтому историю приходится восстанавливать из иных источников разных типов: упоминающихся в научных трудах исторических фактов по паломничеству; документов из архивов Тувы; художественной литературы (произведений тувинских писателей); публицистики, биографических трудов и воспоминаний.

Паломничество имело явное деление по направлениям и по уровню материальных расходов для разных групп населения: поездки в Тибет и Монголию были доступны прежде всего состоятельным людям и ламам, получающим для этого средства, собранные от пожертвований; для простых тувинцев главными объектами поклонений, паломничества были храмы и монастыри, расположенные на территории Тувы, куда они приезжали с мест своих стоянок в дни буддийских праздников.

Все показанные в статье формы паломничества, события, которые их сопровождали, свидетельствуют об интенсивности процесса развития буддизма в Туве в конще ХІХ века. За короткий срок распространения буддизма в Туве он сумел не только стать государственной религией, но и способствовал образовательным, культурным, религиозным связям тувинцев с Монголией, Тибетом, а также Китаем благодаря паломническим поездкам.

Ключевые слова: буддизм; буддизм Тувы; тувинский буддизм; тувинцы; буддист; паломничество; Тува; Монголия; Тибет; Китай; история буддизма; буддийский мир

Подготовлено при финансовой поддержке Российского научного фонда в рамках научного проекта «Россия и буддийский мир в дискурсе философского востоковедения» (грант № 19-18-00118).

\section{Для цитирования:}

Ламажаа Ч. К., Бичелдей У. П. Основные характеристики тувинского буддийского паломничества рубежа XIX-XX веков // Новые исследования Тувы. 2021, № 2. С. 6-17. DOI: https://www.doi.org/10.25178/nit.2021.2.1

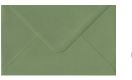

Ламажаа Чимиза Кудер-ооловна - доктор философских наук, приглашенный исследователь Калмыцкого государственного университета имени Б. Б. Городовикова; главный научный сотрудник отдела религиоведения и культурологии Тувинского института гуманитарных и прикладных социально-экономических исследований при Правительстве Республики Тыва. Адрес: 358000, Россия, г. Элиста, ул. Пушкина, д. 11, каб. 111; 66700, Россия, г. Кызыл, ул. Кочетова, д. 4. Тел.: +7 (916) 413-33-85. Эл. адрес: lamazhaa@tuva.asia

Бичелдей Ульяна Павловна - доктор религиоведения (PhD), заведующая отделом религиоведения и культурологии Тувинского института гуманитарных и прикладных социально-экономических исследований при Правительстве Республики Тыва. Адрес: 66700, Россия, г. Кызыл, ул. Кочетова, д. 4. Тел.: +7 (394-22) 2-39-36. Эл. адрес: opei-ool@yandex.ru
} 


\section{The Main Characteristics of Tuvan Buddhist Pilgrimage at the Turn of the 19th-20th Centuries}

\section{Chimiza K. Lamazhaa}

B. B. Gorodovikov Kalmyk State University; Tuvan Institute of Humanities and Applied Social and Economic Research, Russian Federation,

\section{Ulyana P. Bicheldey}

Tuvan Institute of Humanities and Applied Social and Economic Research, Russian Federation

The article presents for the first time the focal characteristics of the Buddhist pilgrimage of Tuvans at the turn of the 19th-20th centuries. They are formulated according to the results of the study of a range of sources. Although the history of the emergence and strengthening of Buddhism in Tuva has been sufficiently studied, the subject matter of pilgrimage has not received attention. The main issue is the absence of the genre of travel notes ("journeys" / "wanderings") written by pilgrims themselves in the historical literature of Tuva. Therefore, the history has to be reconstructed from other sources of different types: historical facts on pilgrimage mentioned in academic works; documents from the archives of Tuva; fiction (works by Tuvan writers); publicistic writings, biographical works and memoirs.

The pilgrimage was clearly divided into categories according to directions and the level of financial expenses among different social groups: trips to Tibet and Mongolia were affordable primarily to wealthy people and lamas who were receiving funds collected from donations for this purpose; in case of ordinary Tuvans, the main sites of their worship and pilgrimage were temples and monasteries located in the territory of Tuva, and they would come there from their nomad camps on Buddhist holidays.

All kinds of pilgrimage shown in the article and the events that went along with them highlight the intensity of the process of development of Buddhism in Tuva in the late 19th century. Within a short time of the spread of Buddhism in Tuva, it managed not only to become the state religion, but also contributed to the educational, cultural, and religious ties of Tuvans with Mongolia, Tibet, and China through pilgrimage tours.

Keywords: Buddhism; Buddhism of Tuva; Tuvan Buddhism; Tuvans; Buddhist; pilgrimage; Tuva; Mongolia; Tibet; China; history of Buddhism; Buddhist world

\section{Financing}

The article was prepared with support from the Russian Science Foundation, grant no. 19-18-00118, "Russia and the Buddhist World in the Discourse of the Philosophy of Oriental Studies".

\section{For citation:}

Lamazhaa Ch. K. and Bicheldey U. P. Osnovnye kharakteristiki tuvinskogo buddiiskogo palomnichestva rubezha XIX-XX vekov [The Main Characteristics of Tuvan Buddhist Pilgrimage at the Turn of the 19th-20th Centuries]. New Research of Tuva, 2021, no. 2, pp. 6-17. (In Russ.). DOI: https://www.doi.org/10.25178/nit.2021.2.1

LAMAZHAA, Chimiza Kuder-oolovna, Doctor of Philosophy, Visiting Researcher, Kalmyk State University; Chief Researcher, Department of Religious Studies and Cultural Studies, Tuvan Institute of Humanities and Applied Social and Economic Research under the Government of Tuva. Postal address: Office 111, 11 Pushkin St., 358000 Elista, Russian Federation; 4 Kochetov St., 667000 Kyzyl, Russian Federation. Tel.: +7 (916) 413-33-85. E-mail: lamazhaa@tuva.asia

ORCID ID: 0000-0003-1813-3605

BICHELDEY, Ulyana Pavlovna, Ph.D (Religious studies), Head, Department of Religious Studies and Cultural Studies, Tuvan Institute of Humanities and Applied Social and Economic Research under the Government of Tuva. Postal address: 4 Kochetov St., 667000 Kyzyl, Russian Federation. Tel.: +7 (394-22) 2-39-36. E-mail: opei-ool@yandex.ru 


\section{Введение}

Принятие Тувой тибетской линии буддизма в XVIII в. (Берзин, 1992: 24; Монгуш, 2001: 34-35), в целом, привело к тому, что тувинская культура обогатилась и стала частью большого буддийского мира. Сам буддизм, по выражению О. М. Хомушку, благодаря «тесной контаминации с традиционными верованиями и культами народов Саяно-Алтая» (Хомушку, 2005: 118) стал народной религией, у тувинцев появились новые святыни одной из мировых религий. Поэтому естественным закономерным этапом развития религиозной жизни в этом регионе стало появление паломничества как одной из форм религиозного поведения.

До недавнего времени исследований по этому аспекту религиозной жизни буддистов тувинцев не проводились. Как пишет М. В. Монгуш, в отличие, например, от соседней Монголии, Тува прежде всего «была пассивно принимающей буддизм страной, нежели воспроизводящей и приумножающей традиции» (Монгуш, 2001: 35). Это относилось и к не столь развитому движению паломничества (особенно в сравнении с Калмыкией, Бурятией, Монголией), которое всегда требовало существенных материальных и финансовых расходов. Поскольку общество различалось резкой социальной дифференциацией (маленький слой богатых и большинство населения, проживающее в нищете и бедности), для основной его части такие расходы были неподъемными. Тем не менее, исследователи приводили отдельные факты, упоминая в первую очередь о поездках тувинцев на паломничество в Монголию (там же: 45, 47, 48; Буддизм, 1992: 167).

Изучение современных форм тувинского буддийского паломничества (Ламажаа, Бичелдей, Монгуш, 2020) привело к логичной постановке вопроса о предыстории этого явления и побудило заняться сбором исторических источников, которые могли бы помочь в восстановлении его основных характеристик. Главной проблемой здесь является отсутствие в исторической литературе Тувы жанра путевых заметок («хождений») самих паломников, который имеется, например, у бурят (Сазыкин, 1989; Павлов, 2007; Барадин, 2002), калмыков (напр., Цыбиков, 1991; см. также: Бакаева, 1994: 57; обзор жанра: Уланов, Бадмаев, Андреева, 2020). Количество их у монголоязычных народов в целом также невелико, тем не менее этот жанр зафиксирован и изучается; начало его истории отсчитывается со второй половины XVIII в. (Сазыкин, 1989: 117). В случае с тувинским буддизмом подобных произведений нет, по крайней мере - не найдено. Поэтому историю приходится восстанавливать из иных источников разных типов. Систематизация собранного материала позволила сформулировать цель данной статьи - анализ исторических особенностей тувинского буддийского паломничества.

Мы разделили наши источники на четыре группы: научные труды по истории тувинского буддизма; документы из архивов Тувы (Национального архива Республики Тыва - далее НА РТ, архива Тувинского института гуманитарных и прикладных социально-экономических исследований при Правительстве Республики Тыва - далее ТИГПИ); художественная литература (произведения тувинских писателей); публицистика, биографические труды и воспоминания.

При этом следует упомянуть о том, что формы паломничества бывают разные и в качестве паломничества в данной работе в первую очередь рассматриваются поездки в определенные времена года для поклонения святым местам, в том числе, в буддийских храмовых комплексах, находящихся в пределах Тувы. Поскольку поездки в отдаленные монастыри Монголии и Тибета буддисты могли совмещать и для того, чтобы поклониться святыням, и чтобы получить религиозное образование, то такие образовательные поездки учитываются как особая форма паломничества ${ }^{1}$. Поездки могут быть как внутренними (в пределах своего региона, но вне мест своего проживания), так и внешними (за пределами региона, страны).

\section{Группы источников}

Разрозненная информация о паломничестве тувинских буддистов периода XIX - начала XX в., прежде всего в Монголию, содержится в ряде публикаций исследователей истории буддизма в Туве М. В. Монгуш, Н. Л. Жуковской (Монгуш, 2001: 45, 47-48; Жуковская, 1992: 167). При этом М. В. Монгуш ссылается на документы фонда № 115 Управления амбын-нойона Танну-Урянхая Центрального государственного архива Республики Тыва (ныне - Национального архива Республики Тыва, далее -

${ }^{1}$ Об этом также пишут другие исследователи. Например, А. Г. Сазыкин отмечает, что первое сочинение бурятского паломника XVIII в. - хамбо-ламы Дамба-Доржи Заяева показывает не только посещение монастырей и поклонение святыням, но и обучение буддийским наукам в тамошних монастырских школах. И там он проучился семь лет, после чего вернулся домой (Сазыкин, 1989: 117). 
HА РТ). Автор монографии «Истории буддизма в Туве (вторая половина VI - конец XX в.)» (Монгуш, 2011), без опоры на которую теперь не обходится ни одно исследование истории буддизма в этом регионе, упомянула несколько сюжетов из документов, но поскольку непосредственно тема паломничества не входила в поле ее интересов, то очевидно автор охватила далеко не все материалы этого фонда.

По проведенным нами подсчетам в фонде № 115 НА РТ имеются около двадцати документов, содержащих разнообразную информацию периода конца XIX - начала XX в. При этом несколько из них уже опубликованы в первых двух томах археографического издания «Собрание архивных документов по истории Тувы» (Тувагийн туухэнд холбогдох ..., 2011ab), подготовленном ТИГПИ совместно с Институтом истории Монгольской академии наук.

Непосредственно к теме данного исследования относятся следующие документы: «Книга доходов и расходов ламского хуре Хемчик Даа хошууна» (НА РТ, ф. 115, оп. 1, ед. хр. 192, на 185 л.); письмо Камбыламы Тувы «Хамбы ламаның бижии» (НА РТ, ф. 115, оп. 1, ед. хр. 192, л. 23); «Список о расходовании вещей верховным правителем Хемчикского хошуна во время поездки в Тибет молиться к Далай-ламе (священному ламе) на 3 луны 32 года БТ (IV-1906 г.)» (НА РТ, ф. 115, оп. 1, ед. хр. 142, л. 117); «Переписка между Буян-Бадыргы по религиозным вопросам» (НА РТ, ф. 115, оп. 1, д. 283a). Еще один интересный архивный документ находится в рукописном фонде архива ТИГПИ - рукопись гелонга Межегейского монастыря Тандынского хошуна О. Ч. Люндупа «Воспоминания о ламской церкви в Туве» (НА ТИГПИ, д. 596), в котором есть упоминания об обучении его в Монголии, а также о поездке группы паломников из Тувы в Монголию ${ }^{1}$.

Помимо этих документальных источников интерес представляют воспоминания тувинцев старшего поколения, зафиксированные в художественной литературе и публицистических изданиях: их детство приходилось на начало XX века и они сохранили в памяти отдельные эпизоды из жизни с родителями, в том числе их паломнические поездки. В художественной литературе эти воспоминания могут быть приукрашены различными художественными приемами, тем не менее, эта информация, вполне может быть рассмотрена как фактологический материал. Подобные сведения имеются, например, в автобиографической повести известного тувинского писателя Кызыл-Эника Кудажы «Самдар Намдар» («Оборванец Намдар») (2005), повести Ондара Сегленмея «Тын дээш демисел» («Воля к жизни) (1980) и др.

Следует отметить, что исследователи истории паломничества монголоязычных народов, также не удовлетворяясь текстами «хождений», которые в первую очередь показывают впечатления образованных, духовных лиц, находят альтернативные источники, чтобы учитывать и жизнь мирян. Например, С. Б. Намсараева вводит в научный оборот текст записи, сделанной сельским учителем и краеведом Б. Б. Намсараевым в 1968 г. на бурятском языке по устным историям старейшины села Судунтуй Читинской области Бато Бадмаева о его путешествии к святыням Тибета в 1901-1904 гг. Исследователь справедливо полагает, что подобные рассказы несут в себе ценные сведения, которые были упущены в путевых дневниках других профессиональных путешественников и хождениях лам (Намсараева, 2020).

Учет всех групп источников позволяет увидеть не только формы паломничества, которые фиксировались официально и были связаны с ламами, но и те, которые совершались мирянами.

\section{Паломничество знати и лам}

Как было упомянуто выше, путешествия за пределы Тувы всегда были затратными мероприятиями, а средства для этого были далеко не у всех. Поэтому паломничество имело явное деление по направлениям и по уровню материальных расходов для разных групп населения: во-первых, поездки в Тибет ${ }^{2}$ и Монголию были доступны прежде всего состоятельным людям и ламам, получающим для

\footnotetext{
${ }^{1}$ Поскольку крупнейший монастырь Гандан г. Улан-Батора имеет свой архив, то в нем, вполне возможно наличие материалов о тувинских паломниках. Аналогичные материалы также могут храниться в архивах приграничных с Тувой Завханского, Кобдинского и Убсунурского аймаков Монголии.

${ }^{2}$ Так как в Туве распространился тибетский вариант буддизма, то главным центром притяжения для тувинских буддистов стала именно эта страна, несмотря на то, что в целом в мировой буддийской традиции первым, наиболее важным местом для поклонений является Индия - место рождения и проповедей Будды. Лишь после того, как в середине XX в. последний духовный лидер Тибета - Его Святейшество Далай-лама XIV покинул свою страну, центром притяжения для тувинских и др. буддистов снова стала Индия, точнее г. Дхарамсала, где располагается ныне его резиденция и находится Правительство Тибета в изгнании (см.: Ламажаа, Бичелдей, Монгуш, 2020).
} 
этого средства, собранные от пожертвований; во-вторых, для простых тувинцев главными объектами поклонений, паломничества были храмы и монастыри, расположенные на территории Тувы, куда они приезжали с мест своих стоянок в дни буддийских праздников. Тем не менее, необходимо сделать оговорку, что простые жители Тувы пограничных с Монголией районов тоже могли совершать паломнические поездки в близлежащие монгольские храмы и монастыри, речь идет прежде всего о тувинцах юга - Тес-Хема, Эрзина ${ }^{1}$.

В паломничество в Тибет и Китай в связи с его удаленностью ездили, в основном, состоятельные люди сами или те, кому они оказывали существенную материальную и финансовую помощь. Как пишет М. В. Монгуш, поездки первых тувинских лам, которые выезжали в Тибет на обучение и проезжали через Монголию, стали возможными благодаря деятельности десятого амбын-нояна Өлзей-Очура (из династии первого тувинского амбын-нойона Тувы Дажы Оюна) в 1870-1880-е гг. (Монгуш, 2001: 45). Известно, что лама Монгуш Лопсан-Чимит (1888-1940), подготовивший впоследствии (в 1928 г.) проект тувинской письменности на основе немецкого алфавита, обучался в Тибете и Монголии в общей сложности 18 лет. Тибетское образование было и у Ондара Лопсана-Чамзы (1857-1930), камбыламы Верхне-Чаданского монастыря и всего Урянхая, который был родным братом угерда Хемчикского Даа хошуна Хайдыпа. Последний стал активным организатором отправки в монастыри Монголии и Тибета тувинских юношей (там же: 47). Более того, в 1906 г. он отправил в Тибет группу тувинских чиновников для подношения даров Далай-ламе XIII и получения от него благословения (там же: 48). Эта информация отмечена в «Книге доходов и расходов ламского хуре Хемчик Даа хошууна» (НА РТ, ф. 115, оп. 1, ед. хр. 192, на 185 л.), где упоминается список «расходованных» вещей правителей хошуна во время поездки.

Одним из тувинских детей небогатого происхождения, но которым возможно помогла поддержка состоятельных тувинцев, сумевшим достичь Тибета и получить там образование, стал родственник К.-Э. Кудажы. В автобиографической повести известного тувинского писателя «Самдар Намдар» («Оборванец Намдар») упоминается дядя со стороны матери - весьма образованный Намбырал лама, который учился в Лхасе. Тот начал свое обучение там с 9 лет и проучился 20 лет. Вернувшись из Тибета, Намбырал лама стал верховным ламой в построенном им самим Хендерге хурээ (на территории нынешнего Чеди-Хольского кожууна). Здесь он служил также с другими ламами. Они давали начальное образование послушникам-хууракам; проводили богослужения, давали наставления населению².

В буддийской школе в Тибете обучался потомственный священнослужитель Шыырап Канданкамбы Долаан (репрессирован в 1939 г.). О нем имеются упоминания в книге народных рассказов о прошлом тувинских семей - книге воспоминаний «Тува. XX век. Народная летопись» (2001). Когда Шыырапу Кандану было 9 лет, в Тибет его отправил отец, имевший сан ламы в монастыре Хендерге. В одном из монастырей Тибета мальчик проучился 10 лет, но, когда до конца учебы оставался всего лишь год, он вернулся в Туву, обзавелся семьей и обратно в Тибет не стал возвращаться. Дома он работал в Хендергинском монастыре вместе с отцом и другими ламами ${ }^{3}$.

Монголия была более доступна для тувинцев, поэтому сведений о поездках в святыни и монастыри этой страны существенно больше. Туда ездили на учебу, для преклонения святым, совершения практик, поклонения Восьмому Богдо-гэгэну Джебцуну Дамба хутухте, которого тувинцы наравне с монголами почитали как живое божество (Жуковская, 1992: 167).

М. В. Монгуш упоминает о паломниках, связанных с именем сына Хайдыпа - следующего угерда Хемчикского хошуна Буяна-Бадыргы. Летом 1909 г. он обращался с официальной просьбой улясутайскому цзянь-цзюню беспрепятственно пропустить через границу верующих аратов из Тувы, которые едут в Ургу - на поклонение хутухте. Причем, в числе паломников была и его мать (Монгуш, 2001: 50). К самому Буяну-Бадыргы обращались за разрешением поехать на учебу в Монголию. Например, в архивных документах найдены его письма со сведениями о фактах обучения тувинцев в Найысылал Хурээ Урги (ныне Гандан монастырь в г. Улан-Баторе) (НА РТ, ф. 115, оп. 1, д. 283a).

\footnotetext{
${ }^{1}$ Так, например, информатор М. В. Монгуш - уроженка Эрзинского района Мыдыкма Мамылдай (родившаяся в 1913 г.) рассказывала о популярности поездок в Ургу у тувинцев, в том числе о своих поездках с родителями. На дорогу у них уходило не менее 15 суток (Монгуш, 2001: 51).

${ }^{2}$ Кудажы К.-Э. Самдар Намдар. Кызыл: Тыванын ном ундурер чери, 2005. С. 5-6.

${ }^{3}$ Тупден Т., Кунгаa А. Кто-то донес... // Тува. XX век. Народная летопись. Кызыл: Республиканская типография, 2001. C. 272-273.
} 
Высшее тувинское духовенство совершало регулярные поездки в Монголию. Так, неоднократные путешествия с жертвоприношениями к его преосвященству Богдо-Гегээну в Монголию отмечались у гелонга Ондара Лопсан-Балдана из сумона Ишкин (из письма Камбы-ламы Тувы «Хамбы ламаның бижии» (НА РТ, ф. 115, оп. 1, ед. хр. 192, л. 23). Гелонг Межегейского монастыря из Танды О. Ч. Люндуп писал: «В 1919 г. во время оккупации Монголии Китаем, я находился в большом монастыре (Гандан) Монголии») (НА ТИГПИ, д. 596, с. 49). В целом, в этот период «С 1918 по 1921 гг. обучался в большом монастыре (т. е. в Гандане, в нынешнем Улан-Баторе. - Ч. Л., У. Б.) в течение трех лет) (там же: 98).

Рядовые ламы также стремились в соседнюю страну, чтобы «помолиться высочайшему Гэгэну и получить от него исцеление» (НА РТ, ф. 115, оп. 1, ед. хр. 142, л. 15-16). Чангы Ёзуту, временно исполняющий управляющего при главном управлении делами Хемчик хошууна Урянхаев, откликаясь на данное процитированное обращение, сделал письменное заключение:

«Из этого нам стало ясно, что люди, которые просят разрешение, действительно хотят освятить себя для будущего счастья. Удовлетворяя их просьбу, выдаем дорожную грамоту в одном экземпляре и просим официальных лиц, ознакомившись с ней, не препятствовать их передвижению, всячески помогая им. Им необходимо при завершении поездки, т. е. при возвращении обратно домой, сдать настоящую грамоту в наше управление ${ }^{1} »$ (там же).

Ч. Дажы-Норбу вспоминала, что в роду Адыг-Тюлюшей был лама, который более 10 лет служил в монгольских монастырях, знал лекарственные свойства растений ${ }^{2}$.

Тувинцы не только отправлялись в паломничество в Монголию ${ }^{3}$, собирая порой «всем миром» пожертвования на дары ${ }^{4}$, на строительство монгольских храмов ${ }^{5}$, но и отправляли туда своих детей ${ }^{6}$ Капитан В. Л. Попов, возглавивший в 1903. Монгольскую экспедицию Сибирского военного округа России в путевых заметках поездки через Саяны и Монголию, помимо всего прочего, отметил, что в Монголии им «пришлось встретить довольно большой караван урянхов ${ }^{7}$, возвращавшихся у гор. Урги, куда более религиозные урянхи ездят на поклонение Богдо-гыгену. Эти паломники ламаизма, конечно, отправляясь за тысячу верст в Ургу, тратят порядочные средства на путешествие и приношения» (Попов, 1905: 131; сохранена грамматика текста. - Ч. Л., У. Б.; см. также: Монгуш, 2001: 51).

В воспоминаниях гелонга (тув. хелин) О. Ч. Люндупа есть рассказ: перед тем как приступить к строительству буддийского монастыря в Самагалтае, которое было примерно в 1786-1788 гг., группа паломников, возглавляемая амбын-нойоном Оюн Тажы, отправилась в г. Ургу с целью преподнесения специальной мандалы (тув. мандыл) Богдо Гегээну Джебцундамбе хутухте хутугта (тув. кудукту, т. е. перерожденец), который восседал в то время в их хурээ (монастыре Гандан в г. Улан-Баторе) и попросили преподать им основы буддийского учения. Во время встречи с паломниками из Тувы, Богдо Гегээн высказал повеление:

«Для вас, тувинцев, основы учения может преподать хутухта, находящийся в монастыре местности ЭртинеБайынды Чиң-ваң аймака Сайын-нояновского управления. Я повелеваю вам испросить основы буддийского

\footnotetext{
${ }^{1}$ Текст цитаты отредактирован с учетом правил современного правописания на русском языке.

${ }^{2}$ Дажы-Норбу Ч. Потомки хозяина тайги // Тува. XX век. Народная летопись. Кызыл: Республиканская типография, 2001. С. 53.

${ }^{3}$ «Записка чангы Ёзуту чангы Борасегетинской погранзаставы о ламах Балдан и Арыя просящих разрешение поехать молиться священному ламе Гегээну в 1903 г.» в «Материалах по религиозным делам» (HA PT, ф. 115, оп. 1, ед. хр. 142, л. 18); «Приказ об управлении шабинарами Джалханза-хутукты правителю Тоджинского хошуна бугдийн-дарга гуну Тонмиту. В связи с тем, что Джалханза-хутукта получил печать Самади багш Номунхана, необходимо прибыть в Ургу, получить божественное благословение и преподнести дары, распределенные по Тоджинскому хошуну» (НА РТ, ф. 115, оп. 1, д. 283, 4.4-5; Тувагийн туухэнд холбогдох ... , 2011b: 142).

4«Запись о поездке в Монголию для поклонения Манчын-ламе в 1898 г.» в «Материалах по религиозным делам» (НА РТ, ф. 115, оп. 1, ед. хр. 142, л. 8); «Распоряжение ухери-да Хайдапа о подношении хандив дацану Жуд (Тантры) халхасского монастыря Дуурэгч-ван хошуна» (НА РТ, ф. 115, оп. 1, д. 163/2; а также: Тувагийн туухэнд холбогдох ... 2011a; 413); «Сообщение о сделанном подношении хандив дацану Тантры халхасского монастыря Дуурэгч-ван хошуна» (НА РТ, ф. 115, оп. 1, д. 142/2; см. также: Тувагийн туухэнд холбогдох ..., 2011а: 415).

${ }_{5}$ «Хувилган ламе Лопсан Данзыну о сборе пожертвований от аратов для постройки хурье (монастыря) при Улястайском чанчыне» в «Материалах по религиозным делам» (НА РТ, ф. 115, оп. 1, ед. хр. 142, л. 157); «О пожертвованиях народа для хурээ бога Суме Ламы-Гегээна в 1903 г.» в «Материалах по религиозным делам» (НА РТ, ф. 115, оп. 1, ед. хр. 142, л. 17).

${ }^{6}$ «Распоряжение об отправке детей на учебу» (НА РТ, ф. 115, оп. 1, д. 167/1; см. также: Тувагийн туухэнд холбогдох ..., 2011а: 423).

${ }^{7}$ Т. е. тувинцев.
} 
учения у этого ламы. А я со своей стороны могу лишь указать вам необходимость отныне начать поклоняться божеству Махакала ${ }^{1}$ и проводить регулярные церемонии его освящения» (НА ТИГПИ, д. 596, с. 2).

По возвращении в Туву паломники снарядили отдельную паломническую экспедицию в указанную Богдо Гегээном местность, где проживал хутугта. Приехав к высокому ламе, посланцы поклонились ему, преподнеся мандалу, и попросили дать посвящение в учение Будды. Хутугта, приняв дар, повелел начать развитие учения Будды в Самагалтайском монастыре с года железной Лошади тринадцатого века Арапчүңа (там же).

В своих воспоминаниях гелонг Люндуп не указывает конкретную дату и год поездки паломнической процессии, возглавляемого амбын-нойоном Оюн Тажы в Ургу. Согласно информации из «Истории Тувы» (История Тувы, 2001: 217), где сделана ссылка на «Историю прежних нойонов тувинского народа», копия которого хранится в рукописном фонде ТИГПИ (РФ НА ТИГПИ, д. 330, с. 2), Оюн Тажи был назначен общим правителем Тувы в 1786 г. В таком случае можно предположить, что события, связанные с поездкой паломников от имени и по предводительству первого тувинского Амбыннойона Оюна Тажы, вначале в Ургу, а затем и в местность Эртине-Буянды Сайын-Нойоновского аймака Монголии, происходили во второй половине 1780-х гг. (РФ НА ТИГПИ, д. 596, с. 35).

Упоминания о паломничестве тувинцев в Китай крайне редки. Обнаружено пока единственное упоминание о поездке на священную гору Утайшань в провинции Шаньси, где расположены древние монастыри и храмы. В своих воспоминаниях вышеупомянутый гелонг Оюн Люндуп сообщает следующую интересную информацию: «...помимо Урги (Улан-Батора) тувинцы также посещали знаменитую гору Утайшань (тув. Удай даг). Паломничество из Тувы в Утайшань были редкими, но имели место быть. Поездки туда из Тувы длились иногда даже год» (РФ НА ТИГПИ, д. 595, с. 35).

В повести «Улуг чалгыг» («Большая волна») народный писатель Тувы С. А. Сарыг-оол привел рассказ чабана Хылбана, который в юности, попав в военный призыв китайских и монгольских управлений, попал в плен к белогвардейцам. События происходили в промежутке 1914-1918 г. Вместе с остальными пленными Хылбан был отправлен в минусинскую тюрьму, затем, по причине происходивших везде столкновений большевиков и белогвардейских войск, вместе с друзьями прошел путь странников из Минусинска в Красноярск, далее в Хабаровск, затем - в Харбин, Мукден. Оттуда они наконец прибыли в Ургу. Оказавшись в Урге, зная, что в Улуг Хурээ (Гандан монастыре) постоянно обучаются тувинские послушники-хувураки, они пришли в монастырь. Здесь они встретились с хувураком (хуураком) из Чадааны (Чадаана) и узнали, что недавно сюда прибыла большая группа паломников из Амбын кожууна Тувы во главе с даа-ламой Чагытайского хурээ Балдаром и Чорбаа, управляющим Салчакского кожууна. Хувурак сопроводил странников к месту, где расположились тувинские паломники, проживавшие в 40 палатках и трех белых юртах рядом с монастырем. Здесь рассказчик встретил свою земляку из Тес кожууна по имени Сирзенмаа 2 .

Все представленные формы паломничества, события, которые их сопровождали, свидетельствуют об интенсивности процесса развития буддизма в Туве в конце XIX века, о чем также пишет М. В. Монгуш (Монгуш, 2001: 45).

\section{Паломничество народа}

Главными объектами для народной формы паломничества были буддийские храмы самой Тувы, которые со второй половины XIX века стали центрами социальной, культурной и экономической жизни.

Известны усилия амбын-нойонов по подготовке лам из числа тувинцев - это было частью их политики насаждения буддизма в Туве. Так, М. В. Монгуш упоминает о приглашениях амбын-нойона Ламажапа в 1850-х гг. лам-учителей из Монголии, чтобы они учили тувинских послушников-хуураков при Самагалтайском хурээ монгольскому и тибетскому языкам, чтению и письму, основам буддийских знаний (Монгуш, 2001: 44). Впоследствии с 1870-х гг. позиции буддизма укреплялись в Хемчикском кожууне при десятом амбын-нойоне Өлзей-Очуре.

В 1905 г. нойоном Хайдыпом был построен Верхне-Чаданский хурээ (ҮстүҮ-Хүрээ), ставший крупнейшим в Туве. В нем также было решено готовить будущих лам. По воспоминаниям очевидцев,

\footnotetext{
${ }^{1}$ Божество - охранник, защитник буддийского учения; один из Дхармапала - гневных божеств буддийской мифологии.

${ }^{2}$ Сарыг-оол С. А. Улуг чалгыг // Сарыг-оол С. А. Собрание сочинений : в 3-х т. Кызыл, 1992. Т. 3. С. $241-242$.
} 
сначала были собраны сто мальчиков восьмилетнего возраста, которых посвятили в послушникихуураки и обучение которых было поручено главе храма Ондар Лопсану Чамзы ${ }^{1}$. Среди них, например, был Куулар Дондук (1888-1932), государственный и политический деятель, ставший впоследствии председателем Президиума Малого хурала Тувинской Народной Республики. После обучения в ВерхнеЧаданском хурээ он продолжил монастырское образование в монастыре Гандан г. Урга (ныне г. УланБатор). Куулару Дондуку пришлось прервать учебу в связи с Синхайской революцией в Китае в 1911 г. и политических перемен в Туве, в которых он впоследствии принял активное участие.

Правой рукой главы Верхне-Чаданского хурээ Лопсана Чамзы был Араптан-геше, о котором мало сведений, но есть упоминания в протоколе всебуддийского съезда 1928 г., где он фигурирует в качестве активного делегата съезда. Во время съезда он был избран членом комиссии для разработки резолюции по заслуженным докладам (РФ НА ТИГПИ, д. 11, с. 159). Упоминания о нем нашла тувинская журналистка И. Качан. Из ее публикации мы узнаем, как тувинцы отдавали детей на обучение:

«Меня повезли учиться, когда мне было семь или восемь лет. Отец посадил меня рядом с собой на коня и повез из Верхнего Ишкина на учебу в местечко у чаданского Устуу-Хурээ - в юрту человека по имени Араптан-кешпи. Привез и оставил, а сам уехал домой. Живя в юрте того ламы, я был тем, кто вставал спозаранок, варил чай, разжигал огонь, ходил за хворостом, носил воду. Вечером меня сажали рядом и обучали тангутской грамоте»².

Жизнь тувинских послушников-хуураков из простых семей в монастырях в целом была сложной. Например, писатель Ондар Сегленмей в повести «Тын дээш демисел» («Воля к жизни») описывает жизнь трех маленьких послушников-земляков Шойдана, Чанзана и Чымба из Бай-Тайгинского района, которые обучались в ҮстүҮ-Хүрээ. Хотя мальчики и старались, ламы не давали им спуску, много нагружали физической работой по уборке, мытью, гоняли их по разным поручениям и даже били

В 1880-х гг. в Туве «буддизм развивается здесь повсеместно, собирая вокруг себя десятки тысяч аратов» (Монгуш, 2001: 45). Это свидетельство монгольского ламы Санчая, приглашенного ӨлзейОчуром в ставку хемчикского угерды, которое приводит М. В. Монгуш.

Очевидно, немалую роль в том, что монастыри стали привлекательными для простого люда, стала не только их потребность в молитвах, поклонениях, но и чисто материальные причины. Монастырские хозяйства имели пастбища, вели торговлю, скупали у аратов пушнину, скот (История Тувы, 2007: 40). Но для того, чтобы реализовывать и религиозную политику, при монастырях организовывались и массовые праздники со сбором средств, угощениями, соревнованиями. Так, Өлзей-Очур в 1870 г. распорядился провести большую пуджу (религиозный праздник поклонения), для чего хемчикский угерда Базыр собрал с жителей близлежащих сумонов значительный запас продуктов для угощения во время праздника. Служба сопровождалась большим скоплением народа (Монгуш, 2001: 45).

Один из таких религиозных праздников, собиравшим много тувинцев-паломников, описывается в известном автобиографическом романе «Повесть о светлом мальчике» С. А. Сарыг-оола. Здесь речь идет о летнем празднике Майдыр у Кыргыстарского хурээ в Эрзине:

«Чем ближе мы подъезжали к хурээ, тем большие толпы паломников присоединялись к нам. Некоторые ехали целыми аалами. Здесь можно было все увидеть - хорошего коня, смелого наездника, красивую девушку. На привалах молодые девушки тщательно умывали свои хорошенькие личики в воде ручейков ... Лошади богачей тоже были разряжены не хуже хозяев. Беднякам вроде меня и подойти к компании богатых нельзя - поднимут на смех»

«По дороге стали попадаться толпы плохо одетых пеших людей. Некоторые несли на шее, вели за руки голых и босоногих ребятишек. Иные, в такой же худой одежонке, ехали по двое, по трое на быках...»5;

«Наконец перед нашими глазами предстало доселе невиданное мною сооружение - буддийский храм. На самой верхушке крыши торчала медная шишка, словно на шапке у чиновника, на всех четырех углах тоже

\footnotetext{
${ }^{1}$ Монгуш А. «Шыдаан» - Чадан? // Тува. XX век. Народная летопись. Кызыл : Республиканская типография, 2001. C. 124.

${ }^{2}$ Качан И. Устуу-Хурээ - случайности не случайны [Электронный ресурс] // Тува.Азия. 2015, 18 июля. URL: https://www.tuva.asia/news/tuva/8086-ustuu-huree.html (дата обращения: 12.01.2021).

${ }^{3}$ Сегленмей (Ондар) Ф. Ш.-Х. Тын дээш демисел. Кызыл : Тувинское книжное издательство, 2008. С. 11.

${ }^{4}$ Сарыг-оол С. Летний праздник и посещение хуре / Сарыг-оол С. Повесть о светлом мальчике [Электронный ресурс] // Радуга Тувы. Детский литературный сайт. URL: http://tuvacheleesh.ru/156 (дата обращения: 12.01.2021).

${ }^{5}$ Там же.
} 
было по шишке. Рядом с хуре было много построек, где жили и учились молодые ламы. По всей опушке привязаны лошади на арканах. Самые знатные расположились близко к хуре, а то и во дворе его, а беднота в лесу» ${ }^{1}$.

Далее писатель описывает увиденное во дворе храма, а также лам, занимавшихся разными делами. Одни читали молитвы, другие оглушительно колотили в медные тарелки. Кругом стоял густой дым от разных курений, сквозь него проступали страшные рожи зверей. Люди кланялись им, стукались лбами об этих идолов. Оглушенный всем происходящим главный герой также принялся усердно молиться и стучать лбом, при этом думал: «Что творилось в моей душе - объяснить невозможно: страх и любопытство, волнение, недоумение. Я совсем забыл бабушкину просьбу помолиться за живых и мертвых» ${ }^{2}$.

С. А. Сарыг-оол хорошо показал, что простые паломники были слабо осведомлены в тонкостях буддийского вероучения, не были в полном смысле слова буддистами. Однако, люди уже были убеждены, что смогут увидеть божество, смогут получить благословение от него:

«Выйдя из хуре, я услышал почтительный шепот со всех сторон:

- Майндыр! Вон сам Майндыр едет!

“Ну вот, теперь наконец я увижу настоящего живого бога”, - успокоенно подумал я и стал выглядывать изза спин людей. Впереди толпы двигалась процессия. Была видна высокая колесница, запряженная людьми. На ней - носилки, покрытые пологом из желтого шелка, откуда высовывалась голова старого седого ламы. Лама важно оглядывал народ.

“Наверное, он и есть Майндыр”, - подумал я, но, протиснувшись ближе, увидел, что этот лама очень некрасивый, с сальным угреватым лицом и большим носом. В передке колесницы была прикреплена зеленая лошадка, которую люди называли божьей лошадью.

$<\ldots>$

Много сил потратить пришлось, пока я, пробравшись сквозь толпу, не очутился рядом с колесницей. Каждому хотелось коснуться реликвий. Народ шел с поднятыми ко лбу ладонями, кланяясь. Из-за этого все натыкались на впереди идущих, толкались, падали, получалась свалка. А совсем близко к колеснице я протиснуться побоялся: стоявший на передке лама размахивал тяжелой палкой, чтобы расчистить путь. Меня бы он уложил, как зайчишку»³.

Каким образом происходили праздники Майдыр у тувинцев также описал Н. Ф. Катанов в дневнике своего путешествия 1889 г. (Катанов, 2011). Он прибыл к буддийскому храму у подножья горы Хайыракан, в котором был организован праздник, и не только описал увиденное, но и сделал зарисовки движения процессии молящихся, расположение лам, групп людей, даже скамеек (там же: 171-174). Также он отметил особенности соревнований борцов, которые состоялись после моления (там же: 174$)$.

На тувинцев, конечно, все великолепие буддийских храмов, пышность церемоний производили неизгладимое впечатление. Будучи в основной массе безграмотными, не владеющими иными языками, они не понимали нюансов богослужений, как писал Н. Ф. Катанов, «из урянхайцев никто не мог рассказать мне содержание тангутских (тибетских) молитв» (там же: 174). Поэтому тувинцы воспринимали в первую очередь только внешнюю форму религиозных обрядов, храмов.

Так, в книге воспоминаний жителей села Самагалтай (в тувинском написании - Самагалдай), которая была издана в 1996 г. в честь 220-летнего юбилея «Самагалдай. Первая столица Тувы» (1996), мы находим воспоминания учителя, ветерана труда Алексея Дамдына. В детстве он с отцом приезжал из чабанской стоянки в Самагалтай, в котором располагался большой храмовый комплекс и к которому приезжало много тувинцев. Он вспоминает, как впервые увидел золотые крыши храмов и поражался их красоте, величию, сверканию золота, которое было и во внутреннем убранстве. В его память остались и богатые ковры, на которых сидели ламы и молились ${ }^{4}$.

Религиозные праздники согласно буддийскому календарю устраивались разные, длились они по несколько дней, и были призваны не только усиливать эффект от коллективного чтения молитв, что считается важным для буддистов, но и насаждать религию народу «сверху» (Монгуш, 2001: 53). М. В. Монгуш заключила, что буддизм,

\footnotetext{
${ }^{1}$ Там же.

${ }^{2}$ Там же.

${ }^{3}$ Там же.

${ }^{4}$ Самагалдай. Первая столица Тувы. Кызыл: Новости Тувы, 1996. С. 99-100.
} 
«приняв весьма простую форму выражения, уверенно шагнул в народные массы. ... Обрядовая сторона невольно вытесняла само содержание буддизма. Это в итоге привело к тому, что внешняя форма обрядов стала важнее, чем их внутреннее содержание» (там же: 53).

При всем многообразии национальных форм буддизма в самых разных странах и регионах мира, очевидно, что буддийское учение приспосабливалось к местным традициям и верованиям, чтобы распространяться и развиваться на разных уровнях: как государственная религия, как религия просвещенных слоев общества, как народный буддизм. Наши наблюдения за современными формами буддийского паломничества у тувинцев-буддистов показали, что с течением времени не многое изменилось, поскольку основная часть населения даже в XXI веке продолжает оставаться буддистами скорее по традиции, не вникая в суть Учения (Ламажаа, Бичелдей, Монгуш, 2020). Тем не менее, религиозная идентичность, объединяющая тувинцев с другими народами, стала не менее важной составной частью их этнокультурной идентичности.

\section{Заключение}

Таким образом, можно констатировать, что за короткий срок распространения буддизма в Туве он сумел не только стать государственной религией (Монгуш, 2001: 55), но и способствовал образовательным, культурным, религиозным связям тувинцев с Монголией, Тибетом, а также Китаем благодаря паломническим поездкам. Наше исследование показывает, что для тувинцев рубежа XIX-XX вв. было два важных направления паломничества буддистов: зарубежное (в Монголию и Тибет) и внутреннее (к святым местам, храмам в пределах самой Тувы). При этом дальние поездки были доступны прежде всего состоятельным людям - знати и ламам, которые получали образование в Тибете и Монголии. Простолюдины совершали паломничества в основном в ближних пределах мест своего проживания.

\section{Благодарности}

Благодарим за помощь в переводах отдельных фрагментов архивных документов со старомонгольского на русский язык д-ра филол. н., проф. Каадыр-оола Алексеевича Бичелдея.

\section{СПИСОК ЛИТЕРАТУРЫ}

Бакаева, Э. П. (1994) Буддизм Калмыкии: историко-этнографическое очерки. Элиста : Калмыцкое книжное издательство. 127 с.

Барадин, Б. (2002) Жизнь в Тангутском монастыре Лавран. Дневник буддийского паломника (1906-1907 гг.). Улан-Удэ : Изд-во Бурятского научного центра СО РАН. 244 с.

Берзин, А. (1992) Тибетский буддизм: история и перспективы развития. Волгоград : б. и. 32 с.

Буддизм (1992) : словарь / Л. Л. Абаева, В. П. Андросов, Э. П. Бакаева и др. ; под общ. ред. Н. Л. Жуковской, А. Н. Игнатовича, В. И. Корнева. М. : Республика. 288 с.

Жуковская, Н. Л. (1992) Ламаизм в Туве // Буддизм (1992) : словарь / Л. Л. Абаева, В. П. Андросов, Э. П. Бакаева и др. ; под общ. ред. Н. Л. Жуковской, А. Н. Игнатовича, В. И. Корнева. М. : Республика. 288 с. С. 167-168.

История Тувы (2001) / под общ. ред. С. И. Вайнштейна, М. Х. Маннай-оола. Новосибирск : Наука. Т. I. 367 с.

История Тувы (2007) : в 3 т. / под общ. ред. В. А. Ламина. Новосибирск : Наука. Т. II. 430 с.

Катанов, Н. Ф. (2011) Очерки Урянхайской земли. Дневник путешествия, исполненного в 1889 году по поручению Императорской Академии наук и Императорского Русского географического общества. Кызыл : ТИГИ при Правительстве РТ. 384 с.

Ламажаа, Ч. К., Бичелдей, У. П., Монгуш, А. В. (2020) Тувинское буддийское паломничество: от традиции к вере // Новые исследования Тувы. № 4. С. 135-155. DOI: https://doi.org/10.25178/nit.2020.4.10

Монгуш, М. В. (2001) История буддизма в Туве (вторая половина VI - конец XX в.). Новосибирск : Наука. 200 с.

Намсараева, С. Б. (2020) О новом источнике «устной истории» бурят о паломничестве по Внутренней Азии в начале XX в. // Oriental Studies. T. 13. № 6. C. 1558-1567. DOI: https://doi.org/10.22162/2619-0990-2020-52-6-15581567

Хомушку, О. М. (2005) Религия в культуре народов Саяно-Алтая. М. : Изд-во РАГС. 228 с.

Павлов, П, А. (2007) Духовные связи российских буддистов с Тибетом в конце XIX - начале XX вв. : автореф. дисс.... к-та ист. н. СПб. 25 с. 
Попов, В. (1905) Через Саяны и Монголию. Очерк путешествия. Омск : Типография Штаба Сибирского военного округа. 177 с.

Сазыкин, А. Г. (1989) Описание Тибета, составленное в XVIII в. бурятским паломником Дамба-Доржи Заяевым // Страны и народы Востока. Вып. XXVI: Средняя и Центральная Азия (география, этнография, история). М. : Наука ; РЗВЛ. С. 117-125.

Тувагийн туухэнд холбогдох архивын баримдын эмхэтгэл. Боть I (1738-1911) = Собрание архивных документов по истории Тувы. Том I (1738-1911) = Тыванын тоогузунге хамааржыр шыгжамырлар бижимелдеринин чыындызы. 1-ги том (1738-1911) (2011a) / гл. ред. С. Чулуун, А. К. Бичелдей. Уланбаатар ; Кызыл : б. и. 498 с.

Тувагийн туухэнд холбогдох архивын баримдын эмхэтгэл. Боть II (1911-1921) = Собрание архивных документов по истории Тувы. Том II (1911-1921) = Тыванын тоогузунге хамааржыр шыгжамырлар бижимелдеринин чыындызы. 2-ги том (1911-1921) (2011b) / гл. ред. С. Чулуун, А. К. Бичелдей. Уланбаатар ; Кызыл : б. и. 469 с.

Уланов, М. С., Бадмаев, В. Н., Андреева, А. А. (2020) Феномен буддийского паломничества в истории и культуре калмыков // Былые годы. Т. 56, вып. 2. С. 398-406. DOI: https://doi.org/10.13187/bg.2020.2.398

Цыбиков, Г. Д. (1991) Избранные труды : в 2 т. Новосибирск : Наука, Сибирское отделение. Т. 1. Буддист-паломник у святынь Тибета. 256 с.

Дата поступления: 01.02.2021 2.

\section{REFERENCES}

Bakaeva, E. P. (1994) Buddizm Kalmykii: istoriko-etnograficheskoe ocherki [Buddhism of Kalmykia: Historical and ethnographic essays]. Elista, Kalmyk Book Publishing House. 127 p. (In Russ.).

Baradin, B. (2002) Zhizn'v Tangutskom monastyre Lavran. Dnevnik buddiiskogo palomnika (1906-1907 gg.) [Life in the Tangut Monastery Lavran. Diary of a Buddhist pilgrim (1906-1907)]. Ulan-Ude, Publishing House of the Buryat Scientific Center SB RAS. 244 p. (In Russ.).

Berzin,A.(1992) Tibetskii buddizm: istoriia i perspektivy razvitiia [Tibetan Buddhism: History and prospects of development]. Volgograd, s. n. 32 p. (In Russ.).

Buddizm [Buddhism] (1992) : A dictionary / L. L. Abaeva, V. P. Androsov, E. P. Bakaeva et al. ; ed. by N. L. Zhukovskaya, A. N. Ignatovich and V. I. Kornev. Moscow, Respublika. 288 p. (In Russ.).

Zhukovskaia, N. L. (1992) Lamaizm v Tuve [Lamaism in Tuva]. In: Buddizm [Buddhism] : A dictionary / L. L. Abaeva, V. P. Androsov, E. P. Bakaeva et al. ; ed. by N. L. Zhukovskaya, A. N. Ignatovich and V. I. Kornev. Moscow, Respublika. 288 p. Pp. 167-168. (In Russ.).

Istoriia Tuvy [The History of Tuva] (2001) : in 2 vols. 2nd ed. / ed. by S. I. Vanshtein and M. Kh. Mannai-ool. Novosibirsk, Nauka. Vol. I. 367 p. (In Russ.).

Istoriia Tuvy [The History of Tuva] (2007): in 3 vols. / ed. by V. A. Lamin. Novosibirsk, Nauka. Vol. 2. 430 p. (In Russ.).

Katanov, N.F.(2011) Ocherki uriankhaiskoi zemli. Dnevnik puteshestviia, ispolnennogo v1889 godu [Essays on the Uriankhai territory. The diary of a journey made in 1889]. Prep., introduction and comm. by A. K. Kuzhuget. Kyzyl, Tuvan Institute for Humanities Research under the Government of the Republic of Tuva. 383 p. (In Russ.).

Lamazhaa, Ch. K., Bicheldey, U. P. and Mongush, A. V. (2020) Tuvinskoe buddiiskoe palomnichestvo: ot traditsii k vere [Tuvan Buddhist pilgrimage: From tradition to the faith]. New Research of Tuva, no. 4, pp. 135-155. (In Russ.). DOI: https:// doi.org/10.25178/nit.2020.4.10

Mongush, M. V. (2001) Istoriia buddizma v Tuve (vtoraia polovina VI - konets XX v.) [The history of Buddhism in Tuva (latter half of the 6th - late 20th cc.)]. Novosibirsk, Nauka. 200 p. (In Russ.).

Namsaraeva, S. B. (2020) O novom istochnike «ustnoi istorii» buriat o palomnichestve po Vnutrennei Azii v nachale XX v. [Buryat oral histories on Inner Asian pilgrimage: Introducing a new source]. Oriental Studies, vol. 13, no. 6, pp. 1558-1567. DOI: https://doi.org/10.22162/2619-0990-2020-52-6-1558-1567

Khomushku, O. M. (2005) Religiia v kul'ture narodov Saiano-Altaia [Religion in the culture of the Sayano-Altai peoples]. Moscow, RAGS. 225 p. (In Russ.).

Pavlov, P, A. (2007) Dukhovnye sviazi rossiiskikh buddistov s Tibetom v kontse XIX - nachale XX vv. [Spiritual relations of Russian Buddhists with Tibet in the late 19th - the early 20th centuries] : Abstract of the Diss.... Candidate of History. St. Petersburg. 25 p. (In Russ.).

Popov, V. (1905) Cherez Saiany i Mongoliiu. Ocherk puteshestviia [Through the Sayans and Mongolia. A travel essay]. Omsk, Printing House of the Siberian Military District Headquarters. 177 p. (In Russ.). 
Sazykin, A. G. (1989) Opisanie Tibeta, sostavlennoe v XVIII v. buriatskim palomnikom Damba-Dorzhi Zaiaevym [Description of Tibet, compiled in the 18th century by the Buryat pilgrim Damba-Dorzhi Zayaev]. In: Strany $i$ narody Vostoka [Countries and peoples of the East]. Issue XXVI: Sredniaia i Tsentral'naia Aziia (geografiia, etnografiia, istoriia) [Soviet Central and Central Asia (geography, ethnography, history)]. Moscow, Nauka, RZVL. Pp. 117-125. (In Russ.).

Tuvagiin tuukhend kholbogdokh arkhivyn barimdyn emkhetgel. Bot' I (1738-1911) = Sobranie arkhivnykh dokumentov po istorii Tuvy. Tom I (1738-1911) = Tyvanyn tooguzunge khamaarzhyr shygzhamyrlar bizhimelderinin chyyndyzy. 1-gi tom (1738-1911) [A collection of archival documents on the history of Tuva. Vol. 1. (1738-1911)] (2011a) / ed. by S. Chuluun and A. K. Bicheldei. Ulanbaatar ; Kyzyl, s. n. 498 p. (In Mong., Russ. and Tuv.).

Tuvagiin tuukhend kholbogdokh arkhivyn barimdyn emkhetgel. Bot' II (1911-1921) = Sobranie arkhivnykh dokumentov po istorii Tuvy. Tom II (1911-1921) = Tyvanyn tooguzunge khamaarzhyr shygzhamyrlar bizhimelderinin chyyndyzy. 2-gi tom (1911-1921) [A collection of archival documents on the history of Tuva. Vol. 2 (1911-1921)]. (2011b) / ed. by S. Chuluun and A. K. Bicheldei. Ulanbaatar ; Kyzyl, s. n. 469 p. (In Mong., Russ. and Tuv.).

Ulanov, M. S., Badmaev, V. N. and Andreeva, A. A. (2020) Fenomen buddiiskogo palomnichestva v istorii i kul'ture kalmykov [The phenomenon of Buddhist pilgrimage in the history and culture of Kalmyks]. Bylye Gody, vol. 56, issue 2, pp. 398-406. (In Russ.). DOI: https://doi.org/10.13187/bg.2020.2.398

Tsybikov, G. D. (1991) Izbrannye trudy [Selected works] : in 2 vols. Novosibirsk, Nauka, Siberian Branch. Vol. 1: Buddistpalomnik u sviatyn' Tibeta [A Buddhist pilgrim at the shrines of Tibet]. 256 p. (In Russ.).

Submission date: 01.02.2021. 